\title{
Павло Гриценко
}

Інститут української мови

Національної академії наук України, Київ

ORCID: 0000-0002-5363-6585; e-mail: hrytsenko_pavlo@ukr.net

\section{Архівувати - досліджувати - повертати із забуття: нотатки до творчого портрету Наталі Хобзей}

\begin{abstract}
Резюме: Дослідницький шлях Наталі Хобзей (1964-2018) позначений цінними студіями про лексику українських карпатських діалектів, регіональними словниками Гуиульська міфологія. Етнолінгвістичний словник (2002), Гуцульські світи. Лексикон (2013), Лексикон львівський: поважно і на жарт $(2009,2012,2015)$, підготовленими до друку діалектними лексиконами інших авторів. Ці праці відчутно розширюють інформацію про лексику та інші структурні рівні українських діалектів. У дослідженнях стверджено виразну самобутність гуцульських говірок, інформаційний потенціал яких досі не розкрито вповні; продемонстровано необхідність залучення до студіювання діалекту автентичних розлогих діалектних текстів, фольклорних записів, давніших етнографічних та діалектологічних праць (як основи зіставного студіювання говірок за іх різночасовими фіксаціями / описами). У працях Н. Хобзей та львівського академічного кола діалектологів реалізовано тріаду актуальних завдань: архівувати кожен елемент говірок як результат народного мовокористування та мовотворенння; досліджувати діалектні явища у просторі, змінах у часі та на тлі народної культури; повертати із забуття в інформаційний науковий простір, віталізувати загрожені на зникнення елементи народної мови.
\end{abstract}

Ключові слова: українські діалекти, гуцульський діалект, гуцульська демонологія, регіональна лексикографія, Хобзей Наталя

\begin{abstract}
To archive - explore - return from the oblivion: notes for the creative portrait of Natalia Khobzey. The research path of Natalia Khobzey (1964-2018) is noted by valuable studies of the vocabulary of Ukrainian Carpathian dialects, regional dictionaries Hutsul mythology. Ethnolinguistic Dictionary (2002), Hutsul Worlds. Lexicon (2013), Lexicon of Lviv: respectfully and in joke (2009, 2012, 2015), as well as prepared for publication dialectal dictionaries of other authors.

These works significantly expand information on lexis and other structural levels of Ukrainian dialects. The studies confirm the expressive originality of the Hutsul dialects, the informative potential of which hasn't been fully disclosed yet. The necessity of involving of the extended authentic dialectal texts, folklore records, old ethnographic and dialectological works to the research of dialect (as the basis for a comparative study of dialects by their fixations / descriptions occurring at different times) is demonstrated. In the works of N. Khobzey and the academic community of Lviv dialectologists the triad of immediate tasks is implemented: to archive each element of dialects as a result of popular language using and language creation; to explore dialectal phenomena in space, temporal changes and on the back of the folk culture; to return from the oblivion to the scientific information space, to vitalize the endangered elements of folk speech.
\end{abstract}

Keywords: Ukrainian dialects, Hutsul dialect, Hutsul demonology, regional lexicography, Khobzey Natalia 
Зміст життя науковця визначають і наповнюють не тільки його індивідуальні пошуки й осягнення, зміни зацікавлень і дослідницьких пріоритетів, а й віддзеркалені в його студіях етапи розвитку відповідної галузі пізнання, наукової школи, до яких він був причетний. Тому пізнання творчості окремої особистості має й загальні виміри як спроба осягнути шляхи розвитку науки, відповідний час та його змістове наповнення. Цю думку підтверджує, зокрема, осмислення дослідницького шляху українського діалектолога Наталі Хобзей (24. V 1964 - 21. VIII 2018): у іiі творчій біографії проступають визначальні ознаки діяльності в кінці XX - на початку XXI ст. львівського академічного осередку мовознавців - відділу української мови Інституту українознавства ім. І. Крип'якевича Національної академії наук України, де відбувалося іiі формування як лінгвіста, де були зреалізовані iii творчі задуми; цей відділ упродовж років вона очолювала.

Випускниця Львівського університету ім. І. Франка Наталя Данчак (Хобзей) потрапила до відділу української мови Інституту суспільних наук УРСР (нині Інституту українознавства ім. І. Крип'якевича НАН України) 1986 року. У той час відділ працював за двома напрямами: історія мови, насамперед - історична лексикографія (після успішного завершення історичного словника української мови XIV-XV ст. колектив продовжував створення лексиконів української мови віддалених епох - укладав словник української мови XVI - 1-ї пол. XVII ст., опрацьовуючи широке коло писемних пам'яток і стародруків; керував проектом Д. Гринчишин) i діалектологія 3 пріоритетною увагою до лінгвістичної географії, лексикології, словотворення (очолювала напрям Я. Закревська). Хоча наукові зацікавлення співробітників сягали різних структурних рівнів української мови, різних епох і навіть різних сфер лінгвістики, проте в центрі уваги залишалося слово - лексика українських діалектів і літературної мови, історія словникового складу, ономастикон.

Діалектологи Інституту великого значення надавали лінгвогеографічним проєктам, працюючи впродовж багатьох років над Атласом украӥнської мови (готували до видання другий том тритомового атласу), беручи участь у міжнародних програмах створення Загальнослов'янського лінгвістичного атласу та Загальнокарпатського діалектологічного атласу; водночас тривало формування лексичної бази для регіонального словника гуцульського діалекту (укладали картотеку, виявляли й опрацьовували рукописні й друковані (нерідко - маловідомі) джерела, здійснювали численні експедиції на Гуцульщину). Спрямування наукових пошуків колективу спричинилися до визначення зацікавлень Н. Хобзей словом у його діалектному бутmі та змінах у часі. Передбачуваним виявився й вибір ареалу студій - Гуцульщина. Вивчення гуцульських говірок і народної культури цього регіону в українській, польській і румунській наукових школах уже мало тривалу історію, та все ж такі дослідження зберігали особливу актуальність, оскільки багато проблем різного масштабу потребувало розв'язання в опорі на нові факти про діалект і традиційну культуру. Адже давніше пізнане, уже устійнене в науці нерідко зумовлювало формулювання нових дослідницьких завдань, спонукало до розширення вихідної емпіричної бази, відкриваючи нові етапи пізнання. Осмислення вже відомої інформації на тлі нових польових записів надавало особливої актуальності проблемі динаміки гуцульського мовного простору, з'ясуванню від- 
ношення між сучасними говірками та їхнім станом, зафіксованим на попередніх часових зрізах, зокрема в кінці XIX - на початку XX ст., коли наукове зацікавлення Гуцульщиною було особливо інтенсивним і результативним.

Розпочавши наукові пошуки із спостережень над номінацією явищ природи в гуцульських говірках ${ }^{1}$ Н. Хобзей згодом зосередилася на вербалізації в гуцульському діалекті широкого кола понять, пов'язаних із віруваннями в надприродні, демонічні сили. Студії над народною демонологією видавалися дослідниці не тільки цікавими, а й незвичними, оскільки спонукали виходити за межі традиційного лексикологічного опису слова, до поєднання мовного й етнологічного аналізу. Таке інноваційне спрямування лінгвістичних досліджень було на часі. Адже від початку 80-х років XX ст. відчутно зростало й набувало нового змісту зацікавлення проблемами взаємовпливів мови й традиційної народної культури; відбувалося активне формування окремого напряму славістики - етнолінгвістики - зі спеціальними завданнями пізнання, прийомами опису матеріалу, оновленням змісту базових понять (як мовний образ [картина] світу, символ [у народній культурі], мовно-ментальний стереотип тощо), окремою системою термінів. Цей науковий напрям відкривав перспективу глибшого пізнання взаємозумовленості мови і культури, форм їх зв'язків і впливів. Становлення в славістиці окремої етнолінгвістичної дослідницької парадигми засвідчили масштабні наукові проекти, які спиралися не лише на синтез раніше зафіксованої й по-новому інтерпретованої інформації, а й на широкі нові матеріали спеціальних експедицій; важливу роль відігравали також нові дослідницькі центри, у яких розробляли масштабні загальнослов'янські наукові програми, навколо яких формувалися школи, закладалися фундаментальні видання ${ }^{2}$.

Етнолінгвістичний рух захопив і Н. Хобзей: вона по-новому відкривала для себе важливий сегмент української культури - розгалужений і варіативний світ гуцульської демонології, витворений упродовж століть народною уявою й утримуваний у свідомості та культурних практиках мешканців краю. До вивчення цього незвичного сегмента традиційної культури Карпат у різний час доклали багато зусиль відомі етнологи, фольклористи, лінгвісти (І. Вагилевич, В. Шухевич, І. Франко, А. Онищук, М. Зубрицький, Б. Заклинський, Л. Гарматій, М. Кобринський, Б. Кобилянський, Р. Кайндль, С. Вінценз, М. Зеленчук, Н. Вархол та ін.), які зібрали й зберегли для широкого кола користувачів майбутніх поколінь цінну етнокультурну й мовну інформацію, подали інтерпретацію багатьох елементів цієї сфери буття гуцулів. Н. Хобзей синтезувала й використала свідчення опублікованих i численних рукописних діалектних та етнологічних джерел із Гуцульщини, удокладнивши наявну інформацію новими експедиційними матеріалами. Записування, аналіз різнопланових свідчень допомогли дослідниці глибше пізнати особливості народної словесної, духовної й матеріальної культури гуцулів, розуміння ними світобудови, довкілля. Світоглядна система, вірування й традиційні культурні практи-

\footnotetext{
Першу наукову розвідку Н. Хобзей присвятила назвам снігопаду в гуцульських говірках (Данчак 1987).

2 Серед численних видань особливе значення мали Славянские древности. Этнолингвистический словарь, Ред. Н.И. Толстой, т. 1-5; М., 1995-2012; Etnolingwistyka, red. J. Bartmiński, Lublin; видання триває від 1988; Кодови словенских култура., ред. Д. Ајдачић, Београд; видання триває від 1996.
} 
ки мешканців гір постали перед Н. Хобзей як складне утворення, багато елементів якого сягає віддалених епох, зберігає глибоку архаїку, що засвідчують насамперед народні назви різноманітних понять, реалій, розгалужена система усталених зворотів і висловів, численні наративи, зміст і форми фольклорних творів.

Матеріали про гуцульську демонологію оприявнили існування тісних зв'язків між двома світами - людським і позалюдським (паралельним, ірреальним), які, попри їх традиційне протиставлення, виявилися не розділеними неперехідною межею, а такими, що мають багато спільного: позалюдський (ірреальний) світ постає олюдненим, антропізованим, наділеним характерними рисами людського буття; 3 „того світу” „mi” могли приходити (повертатися) у людський світ, контактувати з людьми; водночас люди також були здатні переходити у світ „не -людей”, тимчасово перебувати в ньому і повертатися знову у „свій світ”. Н. Хобзей звернула спеціальну увагу на цю особливість світобачення гуцулів їхню тверду віру у взаємодію й тісний зв'язок обох світів. За уявленнями гуцулів, існують люди, наділені надприродними здібностями, здатні впливати (позитивно чи негативно) на життя, здоров'я, добробут інших людей, на живу природу й довкілля; таких людей здебільшого знали (і нині знають) у своєму середовищі й ближчих околицях, до них зверталися по допомогу; за традицією їх називають непростими; такими, щуо щзось знають; земними (земляними) богами. Розкриваючи неповторне й складне сприймання й моделювання гуцулами світу, дослідниця водночас прагне виявити зв'язки зі світом позагуцульським - 3 іншими регіонами України та поза їі межами.

Результати багаторічного студіювання гуцульських назв демонічних істот і пов'язаних із ними понять Н. Хобзей оприявнила в статтях (Хобзей 1996, 2000, 2003a, б) та в спеціальній праці Гуиульська міфологія. Етнолінгвістичний словник (Хобзей 2002). У словникові вона репрезентувала номінативні засоби, а з ними і складну архітектоніку народних вірувань і уявлень гуцулів про міфічних істот, ширше - про надприродні сили. Задля виявлення повноти семантичної структури кожної назви, іiі мотивації Н. Хобзей, виходячи поза сферу народної демонології, широко залучала інформацію про різні сторони буття гуцулів: у центрі їі спостережень - людина з ії щоденною працею, заняттями, життям у родині, а також календарні й сімейні обряди та звичаї, близькі людині тваринний і рослинний світи, нежива природа довкілля. Такі свідчення дослідниця підпорядковувала пізнанню насамперед закономірностей називання понять, реалій народної міфології та з'ясуванню особливостей, умов їх функціонування. Істотно, що проаналізовано також численні евфемізми й перифрази для називання демонічних істот: евфемізми як вторинні номінативні одиниці уможливлювали уникнення в мовленні назв, заборонених чи небажаних відповідно до народних традицій. Крім евфемічних назв демонів зафіксовано широке коло номенів-субститутів на позначення хвороб і смерті, небезпечних для життя людини звірів, плазунів, згадування назв яких так само було небажаним, табуйованим (деякі з цих реалій осмислювано в тісному зв’язку зі світом міфічних істот); традицією табуювання охоплено також назви окремих фізичних станів людини (вагітність, пологи тощо), види господарської діяльності (зокрема вівчарство). Уникаючи в мовленні табуйованих назв реалій, дій, явищ та ознак, носії говірок використовували не тільки вторинні евфемічні 
однослівні номінації, а й усталені (переважно клішовані) звороти, які водночас виконували функцію оберегу (напр.: A mom, ши'ес би к'iшко, к'ішити'і л'уи,'ким гр'іхам = 'А диявол [нехай би щез тяжко] тішиться людськими гріхами' (Хобзей 2002, 66)); на грунті таких словосполук поставали однослівні деривати-евфемізми (щезби, шчезник, шчезун 'диявол'). Зауважимо, що про табу та евфемізми в гуцульському діалектному просторі раніше вже було відомо чимало, насамперед зі студій етнологів і фольклористів (В. Шухевича, В. Гнатюка, І. Франка), мовознавців (М. Грицака, Й. Дзендзелівського), проте реєстр таких вербальних одиниць, зібраних Н. Хобзей, виявився значно ширшим, різноманітнішим за структурою, мотивами номінації, формами та ситуаціями використання в мовленні.

Важливо, що Н. Хобзей звернула увагу на міждіалектні й міжмовні зв'язки гуцульських традицій - на рівні понять, назв і культурних практик із ділянки демонології - з відповідними явищами в територіально суміжних і віддалених українських діалектах / культурних ареалах (зокрема в центрально- та східноукраїнському); підкреслила наявність південнослов'янських (зокрема балканських) відповідників демонологічній лексиці українських карпатських діалектів. Адже виявлення й інтерпретацію карпато-балканських мовних і культурних спільних елементів від середини XIX ст. дослідники розглядають насамперед у контексті міжетнічної взаємодії, давніх і новіших взаємовпливів. Розв'язанню цих актуальних проблем славістики і балканістики свого часу були підпорядковані праці істориків слов'янських мов, дослідників писемних пам'яток та діалектологів (Ю. Венеліна, І. Панькевича, С. Бернштейна, Г. Клепікової, П. Івіча, Й. Дзендзелівського, В. Німчука та ін.), створення Загальнокарпатського діалектологічного атласу. Віднайдення й аналіз кожної нової лексичної чи семантичної карпато(українсько)-балканської паралелі, з'ясування іiї просторових параметрів залишається особливо актуальним для глибшого осмислення питань слов'янської мовної й етнічної історії.

Залученням до аналізу гуцульських міфологічних назв, зафіксованих у давніших писемних пам'ятках, етнологічних описах (яких від середини XIX ст. їх з'явилося чимало), Н. Хобзей актуалізувала діахронний аспект студій, зокрема з'ясування стану збереження номінативних засобів цієї тематичної групи та відповідних культурних практик. Закономірно, що в словникові гуцульської міфології подано зауваження про те, що під час сучасних польових досліджень у говірках, де давніше було зафіксовано мовні риси чи елементи традиційної культури, останні вже не функціонують, вийшли з ужитку чи зазнали відчутних трансформацій.

Структурною особливістю словника гуцульської міфології Н. Хобзей, що вирізняє його на тлі багатьох інших зібрань діалектної лексики, є поєднання власне лексикографічного опису матеріалу 3 монографічним: авторка часто передає й докладно коментує погляди відомих дослідників на походження, географію назв, їхню мотивацію й генезу, а також на давній зміст відповідних культурних дійств, ознак, явищ. У структурі словника помітним $є$ широке використання текстів-ілюстрацій, розлогих наративів із діалектного мовлення в записах різного часу, у яких збережено важливі свідчення про особливості говірок на всіх структурних рівнях; отже, лінгво-етнографічне спрямування 
словника не завадило збереженню багатьох фонетичних та граматичних рис гуцульських говірок.

Після опублікування словника гуцульської міфології Н. Хобзей продовжувала студії над цими говірками: записувала діалектне мовлення, зокрема численні тексти, фіксувала й аналізувала окремі маловідомі назви, опрацьовувала нові діалектні джерела відомих і нових авторів. Гуцульщина залишилася в центрі зацікавлень Н. Хобзей; до того ж увесь колектив діалектологів Інституту українознавства ім. І. Крип'якевича продовжував роботу над картотекою повного словника гуцульського діалекту, записував нові матеріали, розширював коло рукописних і друкованих джерел. На цей час припадає розгортання студіювання Гуцульщини етнологами, істориками, фольклористами й літературознавцями, пожвавлення громадського руху за збереження локальної культури і мови гуцулів.

Важливим осягненням академічного кола діалектологів стало розв'язання багатьох засадничих питань побудови словника гуцульських говірок, зокрема визначення типу лексикону, обсягу залучуваних матеріалів, структури словникової статті (керувала проектом Я. Закревська) ${ }^{3}$. Згодом із картотеки гуцульського словника було дібрано виразні локальні назви, фразеологізми й оформлено цей матеріал як короткий діалектний словник, призначений насамперед для шкільної молоді краю задля поширення знань про своєрідний світ гуцулів (ГгКс) (поява словника відповідала стратегії розвитку гуцульської школи, одним із пріоритетів якої визначено пізнання й збереження традиційної культури і говірок гуцулів). У ці роки з архівних матеріалів відділу було підготовлено до друку й опублікувано лексичні матеріали М. Негрича з говірки села Березови́ Косівського району Івано -Франківської області (Негрич 2008) та М. Грицака про традиційне вівчарство в селі Росішка Рахівського району Закарпатської області (Грицак 2008). Ці публікації підтримували зацікавлення гуцульськими говірками і культурою краю, розширюючи водночас емпіричну базу їх вивчення. Проте ні добірки слів до давніших етнографічних праць, ні короткі словнички не відтворюють розмаїття лексики гуцульських говірок, специфіки мовних традицій їх носіїв. Тому визріла ідея укласти словник, у якому багатоманітне життя гуцулів було б відображене значно ширше порівняно з іншими власне діалектними лексиконами. Н. Хобзей разом з іншими авторами планованого словника прагнула охопити номінативні засоби різноманітних поняттєвих сфер - від профанного щоденного буття до небуденного, високого, сакрального, синтезувавши інформацію не лише власних записів, картотеки гуцульських говірок, а й широкого кола етнологічних студій, художніх творів, фольклорних текстів, численних матеріалів гуцулів-краєзнавців. Цю ідею втілено в словникові Гуиульські світи. Лексикон (Хобзей, Ястремська, Сімович, Дидик-Меуш 2013), у якому укладачі вбачали попередню спробу створення повного словника гуцульського діалекту й водночас розширення кола дослідників і аматорів, яких зацікавить Гуцульщина.

За інформаційним наповненням Гуиульські світи не $є$ традиційним упорядкуванням лише діалектної лексики, як не $\epsilon$ i власне етнографічним словником; це лексикографічний мікс - синтезована форма представлення світу

3 Теоретичні засади та архітектоніку повного словника гуцульського діалекту подано в (ГЛе, $90-270)$ 
гуиулів. Цей унікальний світ подано не лише через сприймання й оцінки дослідників, а й через „внутрішню оптику” - шляхом автокоментування свого життя, мови і культури його носіями. Така засаднича модель словника уможливила широке репрезентування діалектного мовлення, використання розгорнутих ілюстрацій-словосполук, фразеологізмів, паремій, мікро- i макротекстів, за допомогою яких мешканці Гуцульщини називають реалії, пояснюють сутність дій чи обставин, значення та особливості вживання окремих назв у різноманітних комунікативних ситуаціях; ці вербальні засоби передають важливі риси моволаду й мовотворення гуцулів.

Описи щоденного життя, традиційного побуту, звичаїв, обрядодій, як і зауваження щодо ситуацій та умов використання слів, зворотів, наявність обмежень (табу) у слововживанні, спричинилися до відтворення багатьох лексем, словосполук, ексклюзивних значень чи відтінків значень слів, яких раніше не зауважували дослідники гуцульських чи інших українських говірок. Наприклад, лише через докладне пояснення специфічної забави при покійникові (при „грушиі”), один із учасників якої мав назву вірменин, стає зрозумілим зміст виразу де у селі вірменин, та і на царині не буде сіна! 'якщо молодь у селі зайнята іграми (= не роботою), то не буде [заготовлено] сіна' (Хобзей et al. 2013, 142). Зумовленість семантики слова широким позамовним контекстом, можливість витлумачення змісту словосполуки лише через культурний контекст - типова ситуація для мовного буття соціуму з глибокими в часі традиціями. Нерідко семантику лексем, виразів чи фразеологічних одиниць, сутність й особливості культурних практик розуміють лише члени соціуму, а з’ясування значення особами ,з-поза (відповідного) соціуму" (зокрема, і діалектологами, які прагнуть записати інформацію про говірку) нерідко відчутно утруднене, потребує спеціальної попередньої підготовки.

Зумовленість семантичної, нерідко - i формальної структури лексем, фразеологізмів, усталених словосполук позалінгвальними чинниками підтверджує справедливість положення про діалект як явище одночасно мови і традиційної народної культури, наслідок їх взаємодї та взаємозумовленості.

Одним із результатів лексикологічного дослідження й лексикографічної експлікації гуцульського мовно-культурного простору, що впродовж тривалого часу здійснював львівський діалектологічний осередок, а в ньому - i Н. Хобзей, $є$ :

- аргументоване ствердження виразної самобутності цього ареалу українського континууму, інформаційний потенціал якого залишається не розкритим уповні;

- наявність широкого кола елементів, ще не проаналізованих лінгвістами (насамперед етимологами, істориками мови, лінгвогеографами), хоча багато з них мають часово глибоку генезу, точні відповідники в інших зонах Славії, належать до евристично особливо цінних;

- необхідність залучення до студіювання діалекту автентичних (не редагованих під час видання) діалектних текстів (розлогих наративів, діалогів і полілогів між носіями говірок), фольклорних записів (особливо - коломийок), давніших етнографічних та діалектологічних праць (опублікованих i рукописних ${ }^{4}$, що забезпечує зіставне вивчення окремих говірок за їх різночасовими фіксаціями).

4 Важливим джерелом для пізнання гуцульських говірок є упорядковані й опубліковані Я. Pireром архівні діалектні матеріали, які зібрав Я. Янов у міжвоєнний період (LAHDUL; Janów 2001). 
Синтез мовної та загальнокультурної інформації як концептуальну засаду лінгвістичного дослідження Н. Хобзей разом із колегами реалізувала ще в одній фундаментальній праці - Лексикон львівський: поважно і на жарт (Хобзей, Сімович, Ястремська, Дидик-Меуш 2009), що стала етапною в дослідженні українського мовного континууму. Це словник, у якому відтворено не тільки українську мову - слова-назви, типові словосполуки й усталені вирази - окремого міста, а й місто як цілісний соціокультурний феномен, представлений у просторі лексики.

Кожне місто має свою історію, уклад життя, традиції, свої засоби й пріоритетні формули поточного мовлення. Мовним портретом жодне місто не повторює іншого міста. Ситуація мовної індивідуалізованості, виокремленості кожного міста чи невеликого містечка типологічно ідентична відмінностям між говірками, які, належачи до одного діалектного типу, об'єднують у своїй структурі велику кількість диференційних рис. Що більше місто й глибша в часі його історія, що більш різноспрямованими були контакти містян 3 мешканцями інших міст, віддалених поселень, 3 іншими народами і культурами, то ширшим $є$ коло сформованих специфічних ознак мовлення такого міста.

Пізнання континууму мови як цілості передбачає вивчення й урахування особливостей мовлення не тільки сіл, а й містечок і великих міст. Відомо, що локальна мовна традиція міста, вбираючи риси говірок довкілля, водночас впливає на ці говірки, на ближній мовний простір, нерідко відіграє помітну роль у їхньому розвитку. Мовлення міста у своєму впливові на мовне життя поза своїм простором може вирости до загальнонаціонального рівня, як це сталося з мовленням Львова: локальний львівський лінгвальний архетип, сформувавшись упродовж століть і зберігши, попри відчутні іншомовні впливи, українську структурну домінанту, у XIX ст. став основою одного 3 визначальних варіантів нової української літературної мови. На мовний портрет Львова впливали заступлення одних мовних орієнтирів іншими, зміни мови офіційної, яку приносила кожна нова влада краю і що було особливо помітним у XX ст. Та все ж, попри динаміку зовнішніх політичних умов та відчутні іншомовні впливи, лінгвальне буття Львова упродовж століть визначала мовленнєва практика не так неукраїнської аристократії й урядової верхівки, як української автохтонної людності, що забезпечило збереження до сьогодні львівського українського мовного феномену.

Українське мовлення Львова вийшло далеко за береги лише засобу повсякденного комунікування, побутового порозуміння в просторі міста: воно набуло потужності культурного феномена, перетворилося на пізнаваний засіб ідентифікації свого, львівського, на вербальний символ міста, об'єкт мовленнєвої стереотипізації й наслідування. Мода на львівське мовлення зумовила постання своєрідного явища - львівської літератури $з$ притаманною їй особливою львівською мовою й стилістикою, які надаються чіткій ідентифікації, із розмаїтою тематикою, експериментуваннями 3 формою творів тощо 5 . Ці обставини спонукають дослідників до вивчення сучасного й минулого мовлення Львова як складного, багатьма рисами неповторного лінгвального явища.

5 Докладніше див. студію Н. Хобзей у (Хобзей, Сімович, Ястремська, Дидик-Меуш 2009, 9-40).. 
У Лексиконі львівського (проектованого як видання популярне, не для спеціальних потреб мовознавчих студій) представлено елементи мовлення різних соціальних, професійних, вікових верств, культурних течій та осередків Львова, які в реальному житті могли ніколи не перетинатися чи бути пов'язані лише принагідно, проте разом творили цілість, об’єднану мовним кодом, здатністю досягати порозуміння між собою, спільними культурними концептами, локальною історичною пам'яттю, своєрідною мовною аурою міста. Важливо, що у словникові також охоплено мовлення школярів і студентів (міжвоєнного часу й сьогодення), елементи молодіжного жаргону, „балаку батярів”, „таємних мов”, а також стилістично виразно обниженої лексики. Намагання лексикографічно подати мовлення Львова, яке досі залишається остаточно не змодельованим і не описаним як соціолінгвістичний конструкт, поставило авторів перед необхідністю розв'язання низки складних завдань. 3 одного боку, це мав бути словник визначеного географічного простору, що нав'язує дослідження / презентацію мовлення міського соціуму до засадничих основ ареальної лінгвістики, а з іншого, ця праця мала відтворити вербальними засобами середовище Львова як сегментоване, складно організоване утворення - 3 мінливими в одних і консервативними в інших своїх оприявненнях.

Різноплановість завдань Лексикону львівського зумовила його змістове наповнення й формат, зокрема широке використання текстових вставок-інкрустацій різного часу й змісту (від рекламних оголошень, рецептів, уривків із художніх текстів та міського фольклору до „поважної” інформації довідкового зразка), репродукцій малюнків, світлин, що зближує видання з енциклопедіями міста як архетипом праць. Поєднання у викладі різнопланової інформації підтверджує засадничу орієнтацію авторів на дві концептуальні риси - на поважне (наукове відтворення мовної й культурної розмаїтості соціуму міста) і на жарт (використання в лексиконі елементів сміхової культури), що забезпечило легкість сприймання тексту й популярність праці. Обрана авторами модель організації інформації в словнику не затінила його головного змісту: відтворення побутової, культурної й мовної самобутності Львова. Серед слів, словосполук, фразеологізмів, фрагментів текстів чимало таких, які належать минулому, маркують попередні епохи, передають віддалене від сучасного мовлення. Мовне тло лексикону творить поєднання різночасових і різностильових елементів, наявність текстових вставок -інкрустацій. I все ж у міксованому тексті репрезентовано чимало рис локального усного й писемного мовлення, що дозволяє використовувати Львівський лексикон як джерело для вивчення не тільки лексики, семантики, а й синтактики (сполучуваності елементів у мовленні), граматики та фонетики. (Звичайно, це не транскрибований текст усного мовлення, спеціально записаний для потреб мовознавчих досліджень, у якому структура лінгвального ідіому придатна до опромінення аналітичним рентгеном, проте значення, евристичну цінність подібних, здавалося б принагідних, фіксацій мовлення, уже не раз продемонстрували дослідники.)

Формат словника як лінгвістичної праці передбачає виокремлення слова (фразеологізму) як об’єкта аналізу, винесення з глибин на поверхню уваги дослідника рідковживаних, архаїчних елементів, які здебільшого приречені на втрату, забуття. Таку здатність лексиконів - убезпечувати від затирання, ревіталізувати слова, уста- 
лені й вільні словосполуки - переконливо засвідчили і гуцульський словник демонімів, і Гуцульські світи, і Лексикон львівський: у цих словниках вдалося актуалізувати широке коло локальної лексики, специфічних елементів гуцульської і львівської мовленнєвої культури відповідно.

Окрема важлива сторінка діяльності Н. Хобзей та ії колег - едиція діалектологічних праць інших авторів ${ }^{6}$. Окрім згадуваних лексиконів М. Грицака і М. Негрича, опрацьованих до друку під керівництвом Н. Хобзей, особливу цінність - змістом і форматом реалізації - становить підготовлений болехівський словник (Гнатишак 2017). За задумом Юрія Гнатишака (автора лексикону, носія говірки), словник мав би відтворити мовлення містечка Болехова початку XXI ст. і цим затримати від зникнення ті номінативні засоби, які були активно вживані й зрозумілі ще в середині XX ст.7. Цілеспрямоване записування локальної мовної інформації забезпечило надійне представлення в сучасному мовознавстві містечка Болехів як окремого локусу цілісного українськомовного континууму. У цій праці редактори-співупорядники застосували прийоми лексикографування, які опрацювали й апробували в попередніх словниках, зокрема в Гуиульських світах і Лексиконі львівському (широке ілюстрування слововживання слів і фразеологізмів; їх докладне стилістичне та функційне параметризування, зокрема окреслення сфер, особливостей функціонування; наведення невербальної інформації - малюнків, фотографій тощо).

Таким чином, у львівському діалектологічному колі опрацьовано й реалізовано модель регіонального словника діалекту (сільської чи міської спільноти мовців) з пріоритетною увагою не так до усталених формальних лексикографічних канонів діалектної лексикографії, як до повноти лінгвальної інформації лексикону, його когнітивної зорієнтованості. Константними ознаками таких словників залишаються послідовне залучення інформації про позамовне буття носіїв сільської говірки чи мови міста, культурне тло функціонування вербальних елементів, широка опора на докладні тексти, що здатні забезпечити багатовимірність лінгвістичного дослідження, його відчутне поглиблення.

Увага до діалектних текстів як базового джерела інформації під час створення регіональних словників закономірно актуалізувала цілеспрямоване записування усних оповідей (розлогих, нерідко - тематично зорієнтованих, наративів ${ }^{8}$ ) під час експлорації говірок, а також аналіз зібрань давніших записів діалектного мовлення. Зокрема, Н. Хобзей проаналізувала записи текстів, зроблених (здебільшого принагідно) під час обстеження південно-західних говірок за програмою Атласу

6 Про видавничі проекти Н. Хобзей докладніше див. (Гриценко, Ястремська 2018, 7-13).

7 Наявність комунікативних бар'єрів між поколіннями в межах одного діалектного простору спонукала Ю. Гнатишака до записування й упорядкування матеріалів для словника: „<...> у розмові $з$ одним із ровесників нашої Незалежності, мешканцем Болехова, з'ясувалося, що він не розуміє значень деяких слів, якими послуговується місцевий люд. Це і стало поштовхом до усвідомлення того, що зі зміною поколінь ми не тільки маємо здобутки до поступу, але і щось втрачаємо. Із цього моменту розпочалася праця над створенням Словника" (Гнатишак 2017, Двсд).

8 Посилення уваги до текстів, наративів як пріоритетного джерела інформації для вивчення говірок засвідчили представники різних слов'янських діалектологічних шкіл у доповідях на Міжнародній науковій конференції „Діалекти в синхронії та діахронії: текст як джерело лінгвістичних студій” (Київ, 23.-24. III 2015), див. (Двсд). 
украӥнської мови (Хобзей 2011). Про актуалізацію текстологічних досліджень свідчить і спеціальна праця про наративи одного тематичного циклу (тексти про чуда) як явище словесної культури носіїв говірок (Романина 2015). I все ж доводиться констатувати, що тексти як форма реалізації говіркового мовлення, яка має значні інформаційні переваги над записаними за питальниками діалектними матеріалами, ще не достатньо використовують у дослідженнях різних структурних рівнів діалектів, і як наслідок, чимало видань текстів системно не опрацьовано, так само і чимало зон діалектного континууму не(недостатньо) репрезентовано зібраннями текстів.

Отже, розглянуті дослідження Н. Хобзей та іï колег репрезентують пошуки шляхів вивчення українських діалектів, спроби створити й утвердити новий формат регіональних лексиконів. Ці студії засвідчили рух дослідників до:

- пізнання розгалуженої й структурованої лексико-семантичної (тематичної) групи як мікросистеми, до урахування умов і особливостей функціонування слова в різноманітних комунікативних ситуаціях на противагу традиційному аналізові окремої лексеми;

- широкого залучення діалектного тексту - простору буття, реалізації слова до джерельної бази структурних елементів говірок;

- утвердження етнолінгвістичної парадигми аналізу, з'ясування зумовленості форм, значень / функцій мовних одиниць тісними зв'язками 3 традиційною народною культурою.

Наслідком цих змін у вивченні діалектної лексики стало розширення як кола аналізованих елементів і явищ, так і змісту, результатів їх пізнання, а також розвиток прийомів опису й репрезентації мовної інформації, зокрема у форматі регіональних словників. Ці пошуки вкладаються у тріаду визначальних завдань сучасної діалектології:

- архівувати кожен структурний елемент говірки визначеного хронотопу;

- досліджувати явища говірок у континуумі окремої мови та в просторі генетично споріднених і територіально суміжних мов, ураховуючи динаміку діалектів у часі;

- повертати в інформаційний науковий простір, зберігати й віталізувати ті елементи народної мови, яким загрожує зникнення.

\section{Література}

Гнатишак Ю. (2017), Слова з Болехова, співавтори-лексикографи О. Сімович, Н. Хобзей, T. Ястремська [Hnatyshak Yu., Slova z Bolekhova, spivavtory-leksykografy O. Simovich, N. Khobzei, T. Yastremska], Львів.

Грицак М. (2008), Скарби гуцульського говору: Росішка (Вівчарство у текстах), упорядн. Н. Багнюк, В. Шелемех; відпов. ред. Н. Хобзей, Т. Ястремська [Hrytsak M., Skarby hutsulskoho hovoru: Rosishka [Vivcharstvo u tekstakh], uporiadn. N. Bahniuk, V. Shelemekh; vidpov. red. N. Khobzei, T. Yastremska], Львів.

Гриценко П., Ястремська Т., (2018). Наталя Хобзей: у силовому полі украйнської мови, [в:] Далектологічні студіï. 11. Слово - словник - корпус, ред. П. Гриценко, Н. Хобзей [Hrytsenko P., Yastremska T., Natalia Khobzei: u sylovami poli ukrainskoi movi, [v:] 
Dalektolohichni studii. 11. Slovo - slovnyk - korpus, red. P. Hrytsenko, N. Khobzei], Львів, c. $7-13$.

ГгКс, Гуиульські говірки. Короткий словник, укладачі Г. Гузар, Я. Закревська, У. Єдлінська, В. Зеленчук, Н. Хобзей [Hutsulski hovirky. Korotkyi slovnyk, ukladachi, H. Huzar, Ya. Zakrevska, U. Yedlinska, V. Zelenchuk, N. Khobzei], Львів 1997.

ГЛе, Гуиульщина. Лінгвістичні етюди, ред. Я. Закревська [Hutsulshchyna. Lingvistychni etiudy, red. Ya. Zakrevska], Київ 1991.

Данчак Н.В. (1987), Лексика на позначення снігопаду в гуцульському говорі у порівнянні з літературною нормою, [в:] Молоді учені-суспільствознавиі УРСР - 70-річчю Великого Жовтня. Тези респ. наук.-теорет. конф. [Danchak N.V., Leksyka na poznachennia snigopady $v$ hutsulskomu hovori u porivnianni z literaturnoiu normoiu, [v:] Molodi uchenisuspilstvoznavtsi URSR - 70-richchiu Velikoho Zhovtnia. Tezi resp. nauk.-teoret. konf.], Львів.

Двсд, Діалекти в синхронії та діахронії: тексти як джерело лінгвістичних студій, ред. П. Гриценко [Dialekty $v$ synchronii ta diachronii: teksty yak dzherelo lingvistychnykh studii, red. P. Hrytsenko], Київ 2015.

Негрич М. (2008), Скарби гуиульського говору: Березови́, ред. Н. Хобзей, Т. Ястремська, К. Сімович, Г. Дидик-Меуш [Hehrych M., Skarby hutsulskoho hovoru: Berezovy, red. N. Khobzei, T. Yastremska, K. Simovich, H. Dydyk-Meush], Львів.

Романина I. (2015), Структурно-семантичні особливості діалектних текстів про чуда в наддністрянському говорі: дис. ... канд. філол. наук [Romanyna I., Strukturnosemantychni osoblyvosti dialektnykh tekstiv pro chuda v naddnistrianskomu hovori: dis. ... kand. filol. Nauk], Львів.

Хобзей Н. (2002), Гуиульська міфологія. Етнолінгвістичний словник [Khobzei N., Hutsulska mifologiia. Etnolingvistychnyi slovnyk], Львів.

Хобзей Н. (1996), Матеріали для дослідження украӥнської демонології (фольклористичний i мовознавчий аспекти їх збирання), [в:] Украӥнська історична та діалектна лексика, вип. 3, відп. ред.: Д. Гринчишин [Khobzei N. , Materialy dlia doslidzhennia ukrainskoi demonologii [folklorystychnyi $i$ movoznavchyi aspekty yikh zbyrannia], [v:] Ukrainska istorychna ta dialektna leksyka, vyp. 3, vidp. red.: D. Hrynchyshyn], Львів.

Хобзей Н. (2000), Між світом і антисвітом: чоловік, що може перемітуватися на вовка, [в:] Гуиульські говірки. Лінгвістичні та етнолінгвістичні дослідження, ред. Я. Закревська [Khobzei N., Mizh svitom i antysvitom: cholovik, shcho mozhe peremityvatysia na vovka, [v:] Hutsulski hovirky. Lingvistychni ta etnolingvistychni doslidzhennia, red. Ya. Zakrevska], Львів.

Хобзей Н. (2003а), Міфологічні назви у Словнику української мови XVI - першої половини XVII століття, [в:] Діалектологічні студї. 1. Мова у часі i просторі. Збірник на пошану Дмитра Гринчишина, відп. ред. П. Гриценко, Н. Хобзей [Khobzei N., Mifologichni nazvy u Slovniku ukrainskoi movy XVI - pershoi poloviny XVII stolittia, [v:] Dalektolohichni studii.1. Mova u chasi $i$ prostori. Zbirnyk na poshanu Dmytra Hrynchyshchyna, vidp. red. P. Hrytsenko, N. Khobzei], Львів.

Хобзей Н. (2003б), Мовний простір міфологічних назв, [в:] Діалектологічні студії. 2. Мова i культура, відп. ред. П. Гриценко, Н. Хобзей [Khobzei N., Movnyi prostir mifolohichnykh nazv, [v:] Dalektolohichni studii.2. Mova i kultura, vidp. red. P. Hrytsenko, N. Khobzei], Львів.

Хобзей Н. (2011), У просторах воєнного часу. Про першу світову війну в записах для „Атласу украйнської мови”, [в:] Украӥнська мова в Галичині: історичний вимір, відп. 
ред. Я. Ісаєвич, М. Мозер, Н. Хобзей [Khobzei N., U prostorakh voiennoho chasu. Pro pershu svitovu viinu $v$ zapisakh dlia ,Atlasu ukrainskoi movy”, [v:] Ukrainska mova v Halychyni: istorychnyi vymir, vidp. red. Ya. Isaievich, M. Mozer, N. Khobzei], Львів.

Хобзей Н., Сімович К., Ястремська Т., Дидик-Меуш Г. (2009), Лексикон львівський: поважно і на жарт [Khobzei N., Simovich K., Yastremska T., Dydyk-Meush H., Leksykon lvivskyi: povazhno i na zhart], Львів (2 вид. 2012; 3 вид. 2015).

Хобзей Н., Ястремська Т., Сімович О., Дидик-Меуш Г. (2013), Гуиульські світи. Лексикон [Khobzei N., Yastremska T., Simovich O., Dydyk-Meush H., Hutsulski svity. Leksykon]. Львів.

Janów J. (2001), Słownik huculski, opracował i przygotował do druku J. Rieger, Kraków.

LAHDUL, A Lexical Atlas of the Hutsul Dialects of the Ukrainian Language, compiled by J. Rieger, Warsaw 1996. 
